\title{
Training Incentives for Malaysian SMEs: an Impact Evaluation
}

\author{
Corporate Strategy and Insights Department, \\ Pembangunan Sumber Manusia Berhad', Malaysia
}

\begin{abstract}
The article reports on the effectiveness of a Malaysian Government initiative to enhance training within the country's Small and Medium Enterprises (SMEs). The Training Incentives for SMEs Scheme was designed to improve the level of productivity among SMEs by upgrading the skills and capabilities of the existing SME workforce. The Scheme has benefited a total of 16,248 employees from 5,502 employers and they were trained by 276 training providers. The article reports on a study to assess the outcome of the Scheme by measuring the effectiveness based on the perspective of trainees, employers and training providers. In conclusion, the Scheme was effective. Strategic recommendations are developed to improve future schemes by targeting types and content of training programmes, delivery of training programmes and execution of future training programmes and incentive schemes mechanism.
\end{abstract}

Key Words: training, training incentives, SMEs, impact, Malaysia

\section{Introduction}

Small and Medium Enterprises (SMEs) form the backbone of Malaysia's economy and are key to driving the momentum of the nation's growth. Over the last decade, SMEs' Gross Domestic Product (GDP) growth has continuously outpaced Malaysia's overall economic growth. However, SMEs' growth is constantly being constrained by lack of skilled labour resulting in lower productivity rates when compared to larger firms. The Training Incentive for SMEs Scheme was introduced by the Pembangunan Sumber Manusia Berhad (PSMB) (better known as Human Resources Development Fund, HRDF) to support the aspirations of SMEs in developing and improving the level of productivity by upgrading the skills and capabilities of the existing SME workforce.

This article reports on the study undertaken to assess whether the training programmes attended by trainees under the Scheme was effective in improving the trainees' job performance. The study's three main objectives were to:

- Assess the outcome of the Training Incentive against its objectives by measuring the effectiveness of it from the perspective of the trainees, employers, and training providers.

- Identify the problems and challenges associated with the Training Incentive and obtain feedback on areas of improvement from the three target groups (i.e. trainees, employers, and training providers).

- Provide recommendations and develop short and long-term action plans to improve the training programmes offered under such Incentive schemes.

This paper starts by providing a brief contextual profile regarding training within SMEs in Malaysia. It then outlines the methodology associated with this study before reporting on findings. 
A concluding section provides a discussion of the issues associated with the implementation of this scheme and a consideration of the implications for future government backed programmes in order to enhance the training effectiveness within SMEs.

\section{Training and Malaysian SMEs}

The Malaysian Government has long been concerned with the development of SMEs in Malaysia and various strategic plans and initiatives have been formulated to assist SMEs in facing new challenges faced by the changing business environment. This is because SMEs are recognized as a growth driver and an accelerator of economic expansion in Malaysia (Hashim, 2012). Hashim (2012) also argues that apart from their significant share of business establishment (more than $90 \%$ of business establishments in Malaysia are SMEs) and their contribution to the country's income generation (approximately 37\% of Malaysia's GDP), SMEs are also known to provide new job opportunities, introduce innovations, stimulate competition, and form an important link in the supply chain to large multinational companies.

Efficient SMEs have a more educated workforce and are more likely to provide formal structured training to their workers (Batra \& Tan, 2003). However, there are five key challenges faced by SMEs: (1) lack of access to finance, (2) human resource constraints, (3) limited or inability to adopt technology, (4) lack of information on potential markets and customers, and (5) global competition. More importantly, there is a high risk that SMEs will be wiped out if they do not improve their competitiveness in a globalized market that changes at a rapid pace (Ting, 2004). Although there are various factors that are hindering SMEs' competitiveness, the lack of human capital is the most significant challenge for Malaysian SMEs. It is often too expensive for SMEs in Malaysia to employ professional and competent employees (Saleh and Ndubisi, 2006).

\section{The Incentive Scheme}

Realizing the importance of SMEs to the nation, there is acknowledgement from the Government to support the human capital development of SMEs in Malaysia, especially in skills-upgrading for their employees. As such, the agenda of Developing and Retaining a First Class World Talent Base is included as one of the priorities under the Tenth Malaysia Plan (10th MP, Chapter 5). PSMB was given the mandate to upgrade the skills and capabilities of the existing workforce and was entrusted with an allocation of RM47.5 million (for the period 2011 to 2015) to provide training and skills-upgrading to employees of SMEs across Malaysia. This marked the beginning of the SME Training Incentive Scheme.

Specifically the Training Incentive Scheme is to assist SME employers that are registered with PSMB and who pay the levy ${ }^{2}$, but who have insufficient levy balance, to engage some of their employees in training. Training must be in an area of direct benefit to the business operation. Any eligible employer is able to nominate up to three employees to attend a programme run by an external training provider and from a list of approved programmes. In implementing the SME Training Incentive Scheme, PSMB has adopted the latest definition of SME as determined by the SME Corporation Malaysia (SME Corp). The definition is in line with an economic development of the country taking into consideration of price inflation, change in business trends and structural changes. The definition of SME is as stated below: 


\begin{tabular}{|c|c|c|}
\hline Category & Small & Medium \\
\hline \multirow{3}{*}{ Manufacturing } & $\begin{array}{l}\text { Sales turnover from RM300,000 } \\
\text { to less than RM15 million }\end{array}$ & $\begin{array}{l}\text { Sales turnover from RM15 million to } \\
\text { not exceeding RM } 50 \text { million }\end{array}$ \\
\hline & OR & OR \\
\hline & $\begin{array}{l}\text { full-time employees from } 5 \text { to } \\
\text { less than } 75^{*}\end{array}$ & $\begin{array}{l}\text { full-time employees from } 75 \text { to not } \\
\text { exceeding } 200^{*}\end{array}$ \\
\hline \multirow{3}{*}{ Services \& Other Sectors } & $\begin{array}{l}\text { Sales turnover from RM300,000 } \\
\text { to less than RM3 million }\end{array}$ & $\begin{array}{l}\text { Sales turnover from RM3 million to } \\
\text { not exceeding RM } 20 \text { million }\end{array}$ \\
\hline & OR & OR \\
\hline & $\begin{array}{l}\text { full-time employees from } 5 \text { to } \\
\text { less than } 30^{*}\end{array}$ & $\begin{array}{l}\text { full time employees from } 30 \text { to not } \\
\text { exceeding } 75^{*}\end{array}$ \\
\hline
\end{tabular}

Note: *PSMB Act, 2001 refers to the number of employees and paid-up capital during the implementation of the scheme, 10th Malaysia Plan, in determining the eligibility of employers to register.

\section{Table 1: Definition of SME \\ Source: SME Corporation Malaysia}

Employers with one or more following cases - arrears of levy and Interest, involved in PSMB legal cases, in the process of deregistration - are not eligible to participate in the scheme.

\section{The Evaluation}

Measuring and evaluating the effectiveness of training programmes for SMEs and the relevant government support is a relatively complicated matter as it is relatively difficult to measure the direct effects or impact of training (Devins \& Johnson, 2002). In addition, it is more challenging to measure a large number of different training programmes and which evolve over time (LopezAcevedo \& Tinajero, 2010). Therefore, this study is taking the best possible approach to measure training effectiveness. Whilst there are limitations it is better to measure imperfectly rather than the absence of evaluation (Giangreco et al, 2010).

The study assesses the relationship between the quality of the training programmes and the outcomes from the perspective of the trainees, employers, and training providers. The quality of a training programme is determined based on the independent variables which are the quality of the training module, quality of the trainer, quality of the training venue and equipment, the length of the training, the ease of applying for the training, and the frequency of trainees attending training. The effectiveness of a training programme is reflected in the dependent variables which are measured from the perspective of the trainees, employers, and training providers. The moderating variables are variables that moderate the strength of the correlation between the quality of training and the effectiveness. In this study, the moderating variables are the trainee's ability or readiness prior to attending training, the employer's training budget, the barriers to the trainees applying what they learnt at the workplace, and the availability of trainers. The research framework and variables related to this study are shown in Figure 1. 


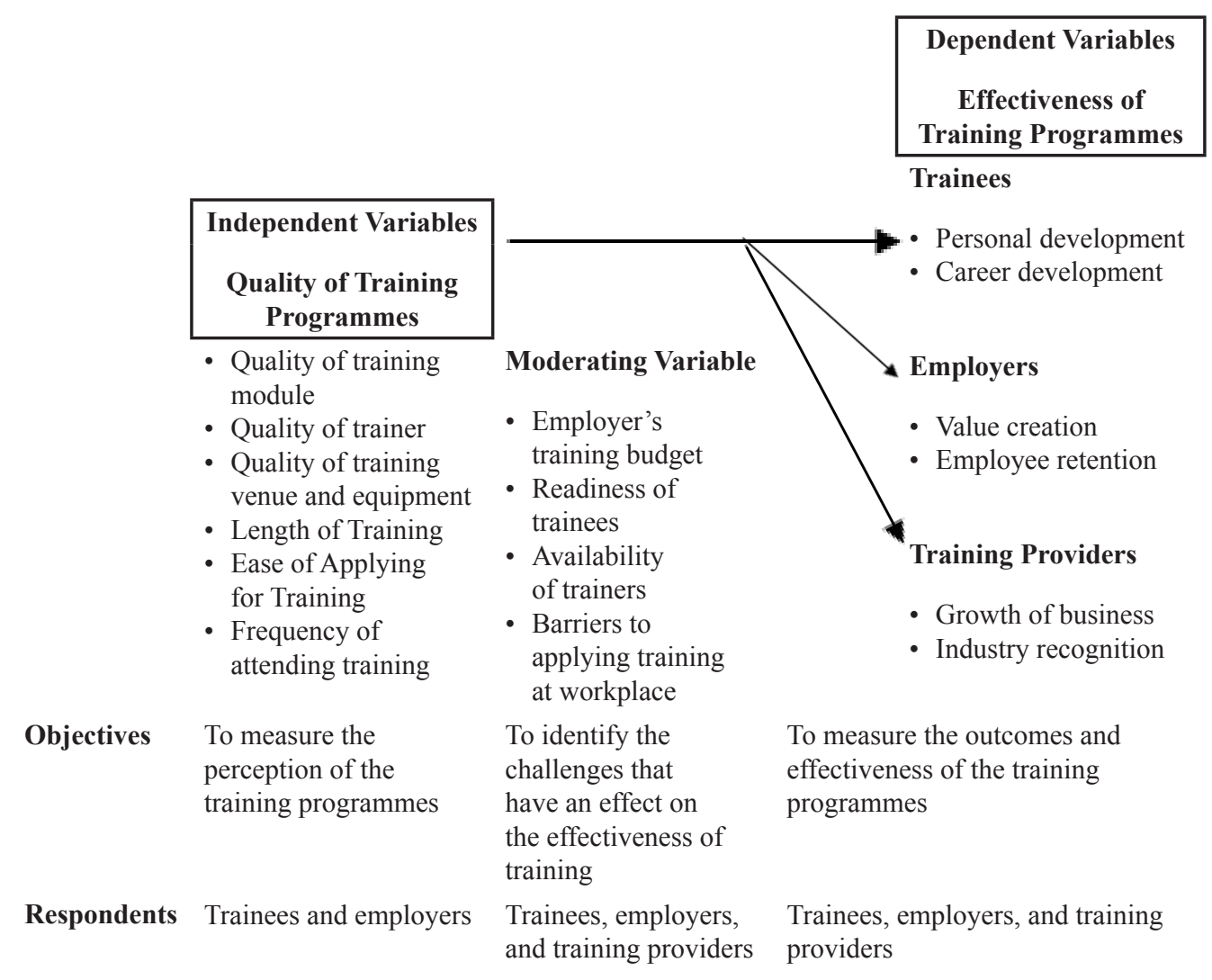

Figure 1: Research Framework for the Study

The study was completed using four main methods which were:

- Consultation with key stakeholders to understand specific needs and issues, share preliminary hypotheses, and obtain the database relevant to the Scheme.

- Secondary research to identify information from previous studies that are related to the current study as well as best practices in other countries in upskilling SME employees.

- Online and telephone quantitative surveys with trainees, employers, and training providers who were participants of the Scheme.

- Workshops and in-depth interviews with the related participants.

\section{Data collection}

A five-point Likert scale quantitative survey ranging from ' 1 = Strongly Agree' to ' 5 = Strongly Disagree' was designed according to the scope of study. Online and telephone quantitative surveys with all trainees, employers, and training providers who were part of the training incentive scheme, were contacted and requested to complete the survey. The database provided by PSMB listed an initial population of 16,248 trainees, 5,502 employers, and 276 training providers. Based on a confidence interval of $95 \%$ and a margin of error of $5 \%$, a sampling framework was established which consisted of 390 trainees, 368 employers, and 131 training providers. 
A pilot study was undertaken. Subsequently, the full survey was conducted with all three target groups. For the employers and training providers, online survey links were emailed to the respective company's person-in charge which enabled them to complete the survey at their convenience. Follow-up calls were made and reminder emails were sent to remind them about the survey and to encourage them to participate.

\section{Data analysis}

First, descriptive statistics are used to provide a general view on what is the average score on each assessment. Next, Chi-square Goodness-of-Fit test is used to determine whether the results from the respondents are equally distributed in their choices in the Likert-Scale.

$\mathrm{H}_{0}$ : The data are consistent with a specified distribution

$\mathrm{H}_{1}$ : The data are not consistent with a specified distribution

Finally, challenges and recommendation from the workshop with respondents are compiled into workshop reports for further discussion.

\section{Findings}

\section{Participant background}

422 trainees participated in the survey and most of them were from the central region $(46.0 \%)$. This is followed by East Malaysia (18.2\%), southern region (16.4\%), northern region (15.6\%) and East Coast of Peninsular Malaysia (3.8\%). In terms of gender, 54.5\% of the respondents were female while $45.5 \%$ were male. The most common highest education attainment for the trainees was Bachelor's degree level where it made up $41.7 \%$ of the total respondents, followed by Diploma (27.0\%), Masters (13.3\%), SPM (9.2\%) and others. Most of the trainees were from the Manufacturing sector (32.4\%), followed by Other Service Activities (13.3\%), Information and Communication (12.8\%), and Education (8.7\%). The majority of the respondents were managers $(39.1 \%)$ while the rest were made up by professionals $(36.7 \%)$, clerical support workers $(11.8 \%)$ and technicians and associate professionals $(6.9 \%)$. The most common working experience in the trainees' current company fell under the category of 4 to 7 years $(30.1 \%)$ and the most common total working experience was the category of 16 to 30 years $(34.1 \%)$.

406 employers participated in the survey and most of them were from the central region (52.2\%), followed by northern region (17.0\%), southern region (14.5\%), East Malaysia (11.3\%) and East Coast $(4.9 \%)$. Slightly more than half of the respondents employ more than 50 employees. About $40 \%$ of all the employers were small companies and the rest were medium companies. In terms of industry breakdown, manufacturing made up $41.9 \%$ of the respondents while the rest were made up of services and others. Most of the respondents were from management positions (42.9\%), followed by respondents who were HR personnel $(29.8 \%)$, Executives $(25.9 \%)$ and Training Personnel (1.5\%).

Most of the 131 Training Provider respondents were based in the central region $(70.2 \%)$ while $10.7 \%$ of them are located in the northern region. Most of the training providers $(69.5 \%)$ specialize in more than one type of training courses (multi specialization). Half of the training 
providers are accredited by local bodies and only $38.9 \%$ of them collaborate with public training institutions. About $52 \%$ of all the training providers collaborate with industry partners when drafting their training modules. Examples of industry partners that training providers work together with include Shell, Hewlett-Packard, Asian Regional Training and Development Organisation, ACCA, and CIMA.

\section{Impact: Participating Trainees}

\section{Trainee satisfaction with training programmes}

There were 13 indicators to gauge trainees' satisfaction. The chi-square goodness-of-fit test was performed on the results of all the indicators to determine whether the distribution of scores is equal among the Likert Scale.

\begin{tabular}{|c|c|c|c|c|c|c|}
\hline \multirow{2}{*}{ Trainees' satisfaction with training } & \multicolumn{5}{|c|}{ Observed frequency } & \multirow{2}{*}{$\mathbf{X}^{2}$} \\
\hline & 1 & 2 & 3 & 4 & 5 & \\
\hline $\begin{array}{l}\text { Training module was applicable and met job } \\
\text { requirements (TM1) }\end{array}$ & 1 & 10 & 56 & 226 & 129 & $418.7 * *$ \\
\hline Training was in-depth (TM2) & 4 & 11 & 90 & 207 & 110 & $326.6^{* *}$ \\
\hline $\begin{array}{l}\text { Training delivered was in-line with training objectives } \\
\text { (TM3) }\end{array}$ & 3 & 7 & 73 & 196 & 143 & $339.3 * *$ \\
\hline Trainer had expertise on the subject matter (TQ1) & 2 & 6 & 61 & 175 & 178 & $360.8^{* *}$ \\
\hline Trainer had good overall attitude (TQ2) & 2 & 4 & 64 & 181 & 171 & $361.4^{* *}$ \\
\hline Trainer was effective in content delivery (TQ3) & 1 & 11 & 74 & 197 & 139 & $333.1^{* *}$ \\
\hline Training venue was accessible (TV1) & 3 & 13 & 82 & 187 & 137 & $296.5^{* *}$ \\
\hline Training venue had good learning environment (TV2) & 2 & 6 & 87 & 189 & 138 & $317.0^{* *}$ \\
\hline Training equipment was of good quality (TA1) & 1 & 14 & 96 & 196 & 115 & $301.4 * *$ \\
\hline Computer/AV equipment was of good quality (TA2) & 4 & 12 & 112 & 186 & 108 & $276.6^{* *}$ \\
\hline Training manual was of good quality (TA3) & 3 & 8 & 90 & 197 & 124 & $316.8^{* *}$ \\
\hline Training duration was effective (TL) & 0 & 14 & 103 & 204 & 101 & $320.0^{* *}$ \\
\hline Overall, the training was of good quality (Overall) & 2 & 4 & 51 & 235 & 130 & $463.6^{* *}$ \\
\hline
\end{tabular}

Table 2: Frequency Distribution of Scores on Trainees Satisfaction with Training Programmes

Results indicate that the frequency distribution is unequal and therefore the null hypothesis is rejected. It is also shown that most of the scores rate between 4-5, suggesting that the trainees are satisfied with the training programme.

Figure 2 shows that all 13 indicators are above 3 (Neutral), indicating overall positive satisfaction in terms of the training conducted in the Scheme. 


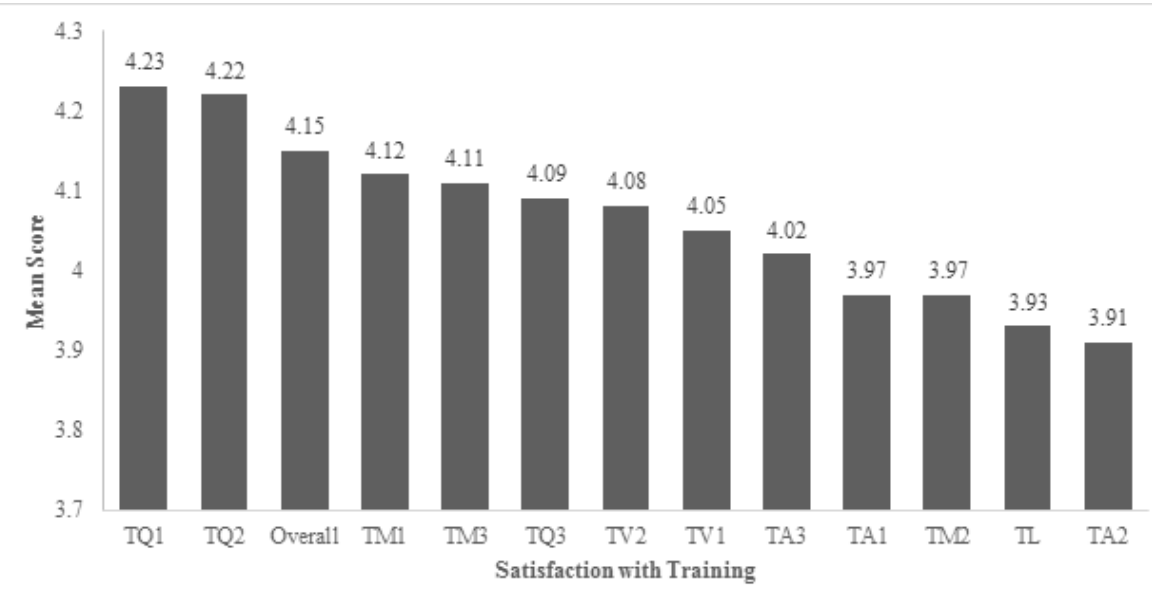

Figure 2: Mean Score of Trainees Satisfaction with Training Programmes

\begin{tabular}{|c|c|c|c|c|c|c|}
\hline \multirow{2}{*}{ Personal Development After Training } & \multicolumn{5}{|c|}{ Observed Frequency } & \multirow{2}{*}{$\mathbf{X}^{2}$} \\
\hline & 1 & 2 & 3 & 4 & 5 & \\
\hline $\begin{array}{l}\text { Training has added to my knowledge on the subject matter } \\
\text { and is useful for my job }\end{array}$ & 0 & 11 & 81 & 191 & 138 & $317.8 * *$ \\
\hline Training has improved my technical skills and is useful for my job & 3 & 18 & 98 & 188 & 114 & $271.1^{* *}$ \\
\hline $\begin{array}{l}\text { Training has enabled me to improve the quality of the } \\
\text { products/services produced by me }\end{array}$ & 1 & 17 & 90 & 197 & 116 & $299.4^{* *}$ \\
\hline Training has enabled me to contribute new ideas to the company & 3 & 10 & 108 & 187 & 113 & $285.8^{* *}$ \\
\hline $\begin{array}{l}\text { Training has enabled me to improve my efficiency and reduce } \\
\text { wastage }\end{array}$ & 4 & 9 & 110 & 185 & 113 & $282.0^{* *}$ \\
\hline $\begin{array}{l}\text { Training has improved customer satisfaction as I am now } \\
\text { better at handling/engaging with my customers }\end{array}$ & 4 & 11 & 115 & 160 & 131 & $245.5 * *$ \\
\hline $\begin{array}{l}\text { Training has motivated me and improved my attitude towards } \\
\text { my work }\end{array}$ & 1 & 9 & 72 & 186 & 153 & $330.4^{* *}$ \\
\hline Training has expanded my professional network & 6 & 12 & 85 & 182 & 136 & $280.0^{* *}$ \\
\hline $\begin{array}{l}\text { Training has enabled me to better understand my company's } \\
\text { organizational goals and align my goals to them }\end{array}$ & 9 & 9 & 102 & 194 & 107 & $287.4 * *$ \\
\hline $\begin{array}{l}\text { Training has enabled me to contribute to increased company } \\
\text { revenue }\end{array}$ & 16 & 18 & 155 & 156 & 76 & $228.8^{* *}$ \\
\hline $\begin{array}{l}\text { Training has enabled me to contribute to reduced costs for the } \\
\text { company }\end{array}$ & 18 & 26 & 137 & 157 & 83 & $188.3^{* *}$ \\
\hline $\begin{array}{l}\text { Training has enabled me to contribute to increased } \\
\text { profitability for the company }\end{array}$ & 11 & 17 & 150 & 164 & 79 & $244.6^{* *}$ \\
\hline $\begin{array}{l}\text { Training has enabled me to be more efficient which has } \\
\text { contributed to the company's productivity }\end{array}$ & 2 & 8 & 90 & 209 & 112 & $343.8 * *$ \\
\hline
\end{tabular}

( $1=$ Strong disagree, $2=$ Disagree, $3=$ Neutral, 4=Agree, $5=$ Strongly agree $)$

$$
* \mathrm{p}<0.05 \quad * * \mathrm{p}<0.01
$$

Table 3: Frequency Distribution of Scores on Personal Development 


\section{Personal development}

13 indicators were used to measure trainees' personal development after attending training programmes under the Scheme. The chi-square goodness-of-fit test was performed on the results of all the indicators to determine whether the distribution of scores is equal among the Likert Scale.

Similar to previous section, results mean rejection of the null hypothesis. Most of the scores are rated between 4 to 5 , indicating that the trainees experienced personal development after attending the training programmes under the Scheme.

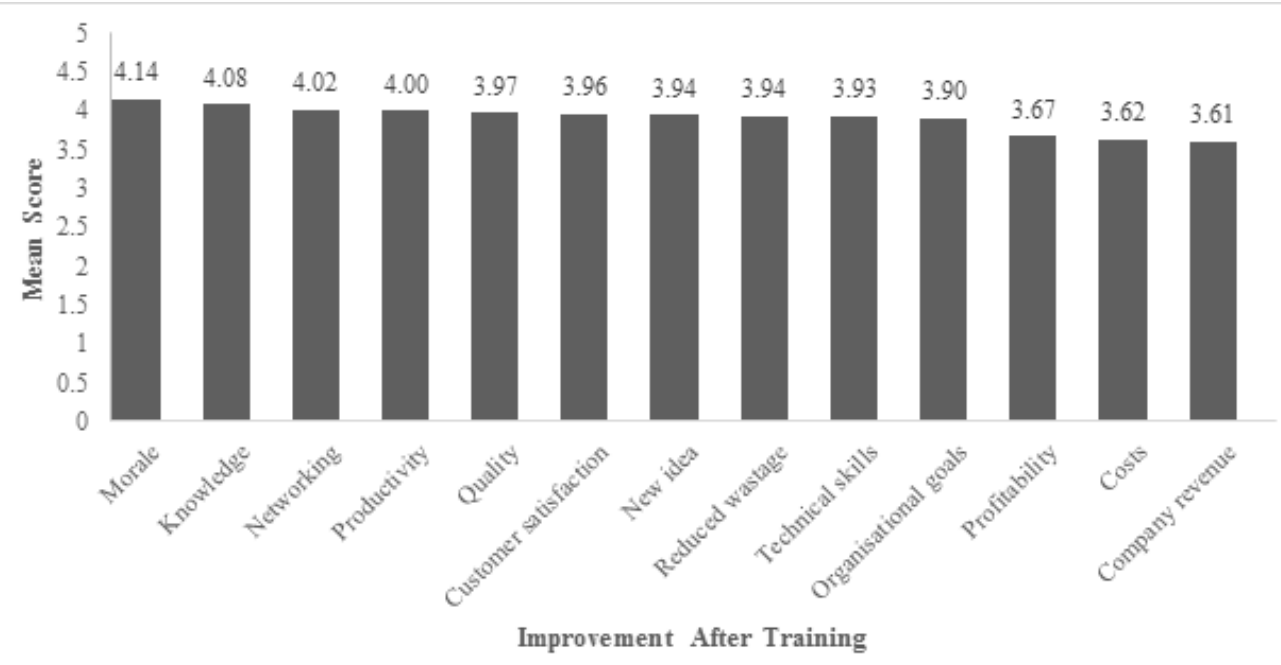

Figure 3: Mean Score of Personal Development after Training Programmes

Figure 3 shows that all 13 indicators are above 3 (Neutral), indicating overall improved personal development after the training conducted in the Scheme.

\section{Career development}

$121(28.7 \%)$ respondents indicated that they did receive a promotion after attending training. Of this number, $51.2 \%$ agreed that the promotion was due to the training programme attended. According to Table 4, out of the 422 trainees who responded to the question, 303 (71.8\%) agreed or strongly agreed that they were sent for training because their employer wanted to encourage them to remain with the company. Consequently, there were $344(81.5 \%)$ trainees who responded that they had not quit their jobs after the training and are still with the same company.

In Table 5, based on the replies of the 74 trainees who did quit their jobs after attending the training programmes, $60 \%$ left because of better job offers, $14 \%$ because they were dissatisfied with their job. About $46 \%$ of the 74 trainees that did quit their job after the training programme stated that their change of employment had nothing to do with the training programme they attended. Only about $11 \%$ revealed that they quit their jobs completely due to the training attended. 


\begin{tabular}{|c|c|c|c|c|c|c|c|c|}
\hline \multirow{2}{*}{$\begin{array}{l}\text { Expectation that } \\
\text { Training was } \\
\text { to Encourage } \\
\text { Retention }\end{array}$} & \multicolumn{7}{|c|}{ Actual Length of Stay After Training } & \multirow[b]{2}{*}{$\begin{array}{c}\text { Grand } \\
\text { Total }\end{array}$} \\
\hline & $\begin{array}{l}<30 \\
\text { days }\end{array}$ & $\begin{array}{c}<3 \\
\text { months }\end{array}$ & $\begin{array}{c}<6 \\
\text { months }\end{array}$ & $<1$ year & $>1$ year & $\begin{array}{l}\text { Did not } \\
\text { quit job }\end{array}$ & $\mathbf{n} / \mathbf{a}$ & \\
\hline 1 & 1 & & & 1 & 1 & 7 & 1 & 11 \\
\hline 2 & & 1 & & 1 & 1 & 15 & & 18 \\
\hline 3 & 3 & 6 & 5 & 4 & 4 & 67 & 1 & 90 \\
\hline 4 & 2 & 6 & 3 & 5 & 12 & 156 & 1 & 185 \\
\hline 5 & 2 & 3 & & 5 & 8 & 99 & 1 & 118 \\
\hline Grand Total & 8 & 16 & 8 & 16 & 26 & 344 & 4 & 422 \\
\hline
\end{tabular}

Table 4: Matrix of Trainees' Expectations That Training was to Encourage Retention vs. Length of Stay after Training

\begin{tabular}{lccc}
\hline \multicolumn{1}{c}{ Current Job Classification } & \multicolumn{2}{c}{$\begin{array}{c}\text { Trainees quit their jobs after } \\
\text { attending training }\end{array}$} & Turnover rate \\
& No & Yes & \\
\hline Managers & 134 & 31 & $18.8 \%$ \\
Professionals & 125 & 26 & $17.2 \%$ \\
Clerical Support Workers & 46 & 4 & $8.0 \%$ \\
Technicians and Associate Professionals & 22 & 7 & $24.1 \%$ \\
Service and Sales Workers & 16 & 3 & $15.8 \%$ \\
Craft and Related Trades Workers & 0 & 2 & $100.0 \%$ \\
Elementary Occupations & 1 & 1 & $50.0 \%$ \\
Total & $\mathbf{3 4 4}$ & $\mathbf{7 4}$ & $\mathbf{1 7 . 5 \%}$ \\
\hline
\end{tabular}

Table 5: Trainees Turnover Rate by Job Classification

In terms of receiving a professional certificate after attending the training programmes, about $49 \%$ of the trainees stated that they did receive a professional certificate. Out of those that did receive a certificate, about $83 \%$ of them believe that their certificate is an industry recognized certification.

\section{Impact: Participating Employers}

\section{Value creation}

In Table 6 and Figure 4, the results suggest that the employers responded that they are neutral with most of the indicators. Only for the indicator on improving company productivity did employers mostly agreed with the indicator.

The results in Table 7 and Figure 5 present the findings on the non-financial impact of the training incentive programme. It suggests that the employers responded that they are either neutral or agreed with most of the indicators. 


\begin{tabular}{|c|c|c|c|c|c|c|}
\hline \multirow{2}{*}{ Financial impact of training } & \multicolumn{5}{|c|}{ Observed frequency } & \multirow{2}{*}{$\mathbf{X}^{2}$} \\
\hline & 1 & 2 & 3 & 4 & 5 & \\
\hline $\begin{array}{l}\text { Company revenue has increased after employees attended } \\
\text { training }\end{array}$ & 10 & 76 & 226 & 86 & 5 & $395.7 * *$ \\
\hline $\begin{array}{l}\text { Operational cost of company has reduced as employee is } \\
\text { more efficient }\end{array}$ & 12 & 54 & 207 & 123 & 7 & $354.9 * *$ \\
\hline $\begin{array}{l}\text { Company profitability has increased after employee attended } \\
\text { training }\end{array}$ & 10 & 67 & 220 & 96 & 10 & $370.0^{* *}$ \\
\hline $\begin{array}{l}\text { Company productivity has improved as employee is more } \\
\text { efficient }\end{array}$ & 9 & 32 & 160 & 185 & 17 & $356.5^{* *}$ \\
\hline
\end{tabular}

$$
\begin{aligned}
& \text { ( } 1=\text { Strong disagree, } 2=\text { Disagree, } 3=\text { Neutral, 4=Agree, } 5=\text { Strongly agree }) \\
& * \mathrm{p}<0.05 \quad * * \mathrm{p}<0.01
\end{aligned}
$$

Table 6: Financial Impact of Training on Employers

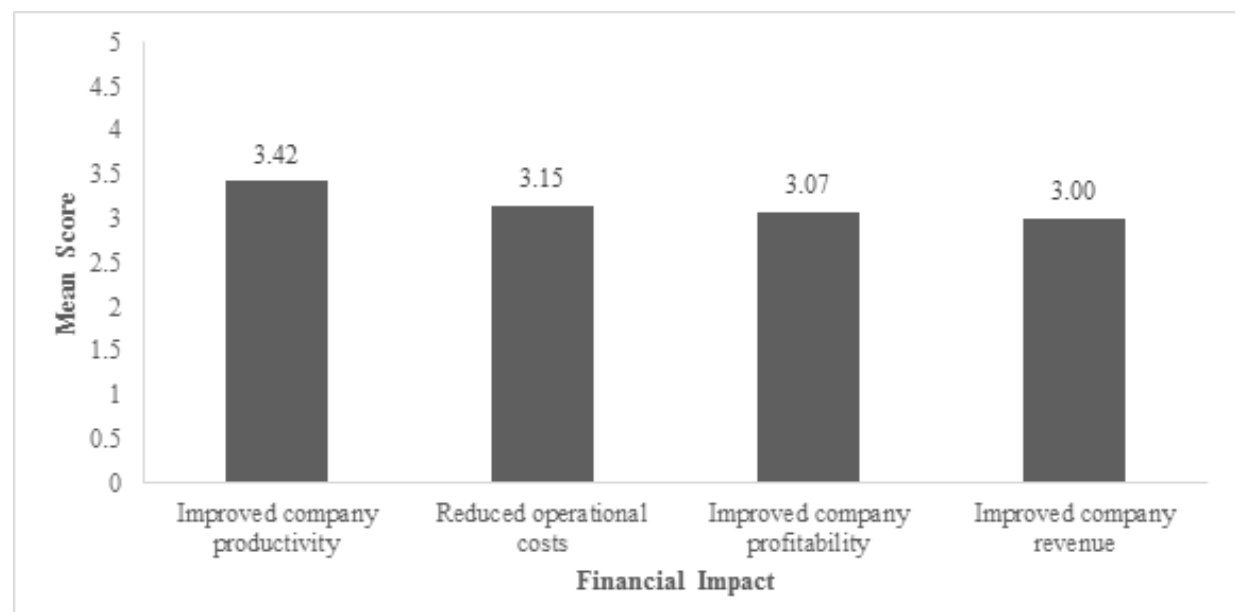

Figure 4: Mean Score of Financial Impact of Training on Employers

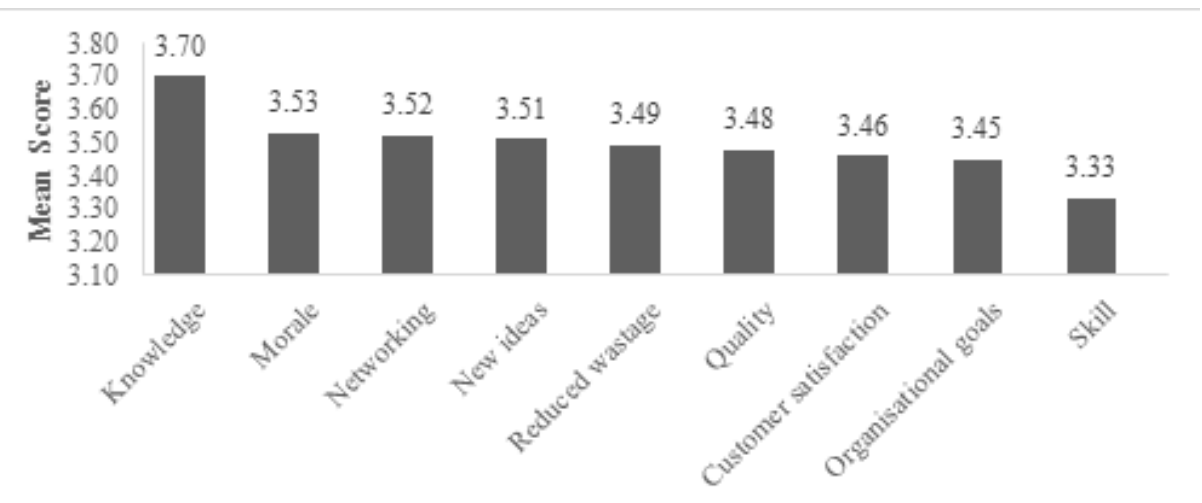

Non-Financial Impact

Figure 5: Mean Score of Non-Financial Impact of Training on Employers 


\begin{tabular}{|c|c|c|c|c|c|c|}
\hline \multirow{2}{*}{ Non-financial impact of training } & \multicolumn{5}{|c|}{ Observed frequency } & \multirow{2}{*}{$\mathbf{X}^{2}$} \\
\hline & 1 & 2 & 3 & 4 & 5 & \\
\hline $\begin{array}{l}\text { My company has tackled skills shortage or skills gaps in } \\
\text { the company }\end{array}$ & 7 & 43 & 177 & 163 & 14 & $338.5 * *$ \\
\hline $\begin{array}{l}\text { My employees have gained new knowledge which is useful } \\
\text { for the company }\end{array}$ & 4 & 10 & 123 & 233 & 34 & $470.9 * *$ \\
\hline $\begin{array}{l}\text { My employees' goals are more aligned with the company's } \\
\text { goals }\end{array}$ & 3 & 29 & 177 & 175 & 20 & $378.2 * *$ \\
\hline $\begin{array}{l}\text { My employee is able to present more new ideas to the } \\
\text { company }\end{array}$ & 4 & 21 & 165 & 192 & 22 & $400.8^{* *}$ \\
\hline $\begin{array}{l}\text { My employee is more aware about reducing wastage in the } \\
\text { company }\end{array}$ & 5 & 24 & 168 & 184 & 23 & $378.3^{* *}$ \\
\hline $\begin{array}{l}\text { Product/service quality has improved after my employee } \\
\text { attended training }\end{array}$ & 4 & 29 & 163 & 185 & 23 & $365.6^{* *}$ \\
\hline $\begin{array}{l}\text { Customer satisfaction and loyalty has improved as my } \\
\text { employee is better trained to handle customers }\end{array}$ & 6 & 24 & 179 & 170 & 25 & $365.5^{* *}$ \\
\hline $\begin{array}{l}\text { My employee is more motivated and shows positive attitude } \\
\text { at work after training }\end{array}$ & 4 & 19 & 163 & 194 & 24 & $402.4 * *$ \\
\hline $\begin{array}{l}\text { The training has enabled my employee to expand his/her } \\
\text { professional network which ultimately benefits the company }\end{array}$ & 4 & 21 & 166 & 186 & 27 & $379.9 * *$ \\
\hline
\end{tabular}

( $1=$ Strong disagree, $2=$ Disagree, $3=$ Neutral, $4=$ Agree, $5=$ Strongly agree)

$$
* \mathrm{p}<0.05 \quad * * \mathrm{p}<0.01
$$

Table 7: Non-Financial Impact of Training on Employers

\section{Staff retention/turnover}

The majority of employers felt that there was no difference in the company's average turnover rate and the turnover rate for employees who have attended training. 17.1\% of employers replied that turnover decreased for employees who have attended training while $16.1 \%$ of the employers felt that turnover increased.

\begin{tabular}{lc}
\hline Group & Observed frequency \\
\hline Turnover increased after training & 65 \\
Turnover decreased after training & 69 \\
No difference in turnover rate & 269 \\
Total & $\mathbf{4 0 3}$ \\
\hline
\end{tabular}

Table 8: Change in Employee Turnover Rate after Attending Training

\section{Impact: Training Providers}

\section{Growth of business}

Between 2011 and 2015, about 82\% of the training providers have enjoyed an increase in profitability. In general, most training providers also increased the number of their trainers as well 
as the number of training programmes they offer. Of those that saw an increase in profitability between those years, $75.3 \%$ attributed that increase at least a little due to their participation in the Training Incentive for SMEs scheme.

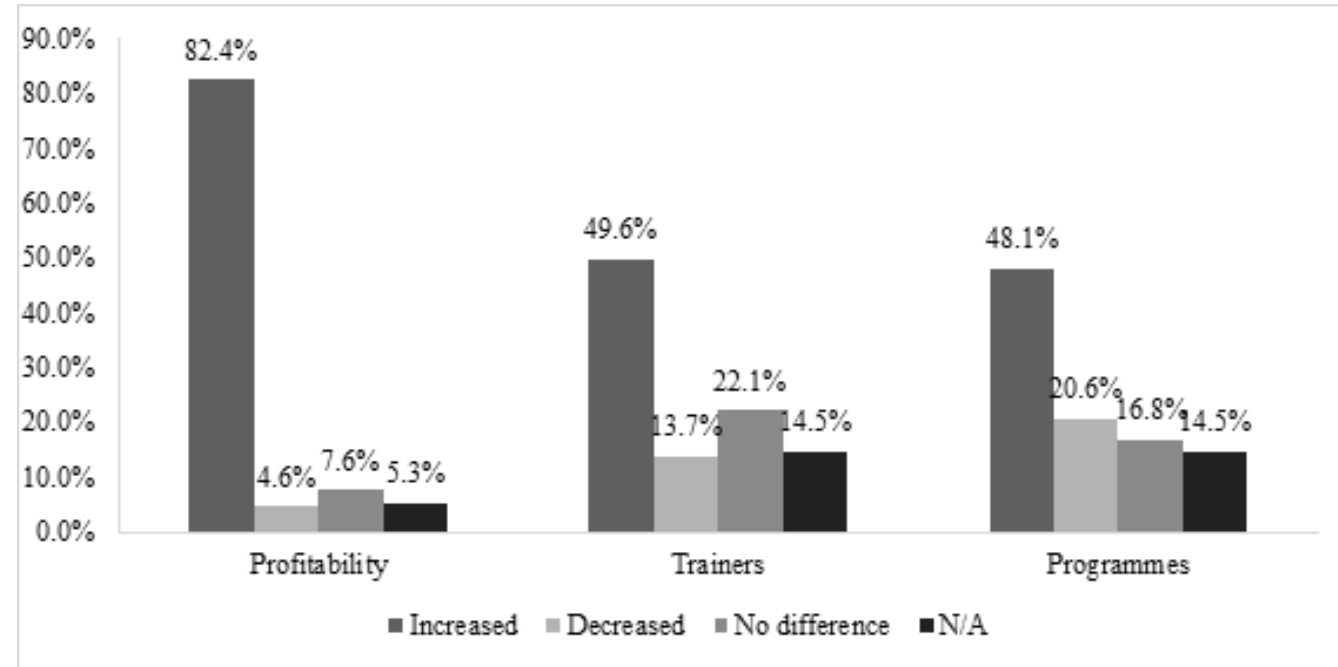

Figure 6: Training Providers' Growth of Business Between 2011 and 2015

The majority of the training providers $(82.9 \%)$ who responded to the survey agreed that their brand awareness increased during their participation in the Training Incentive for SMEs scheme.

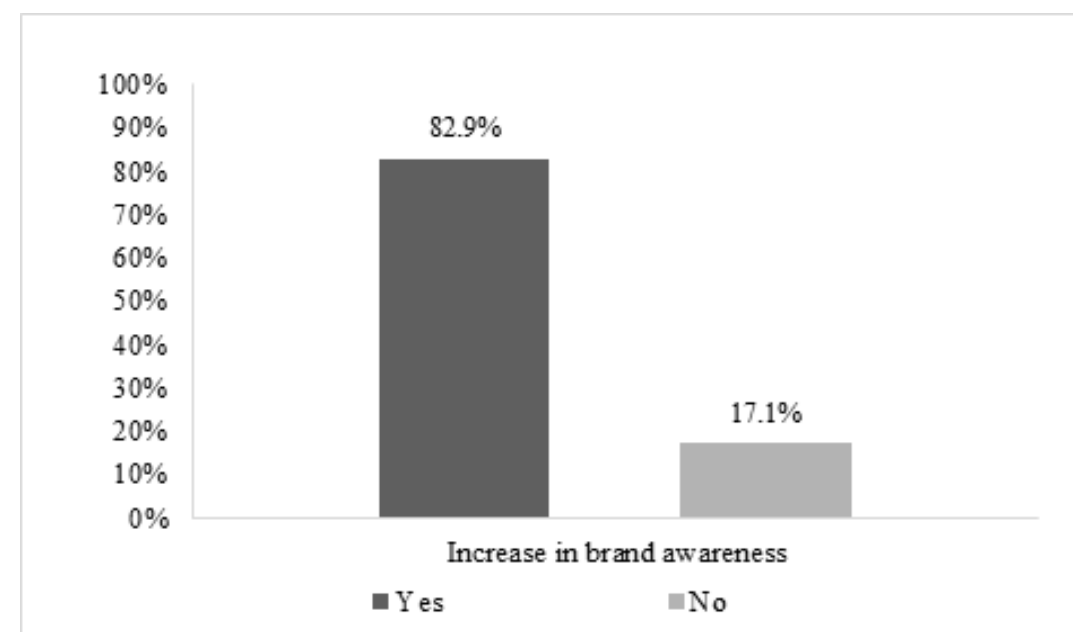

Figure 7: Training Providers' Agreement on Increase in Brand Awareness after Participating in Scheme

\section{Discussion}

Recognising the importance of training and upskilling towards improving SMEs' labour productivity, the government introduced the Training Incentive for SMEs scheme as part of the 
10th Malaysia Plan. The scheme was meant to assist SMEs to continuously retrain and upgrade the skills of their employees. This study was conducted to assess the outcome of the scheme against its objectives by measuring its effectiveness from the perspective of the trainees, employers, and training providers who participated in the scheme. According to PSMB's categorisation, effectiveness of any programme is measured as below:

Not effective: $<50 \%$ achievement of objectives or a Likert scale rating of 1 to 2.99

Effective: Achievement of $50 \%-70 \%$ of objectives or a Likert scale rating of 3 to 3.99

Very effective: Achievement of $70 \%$ and above of objective or a Likert scale rating of 4 to 5

The survey results indicate that the training programmes which were part of the Training Incentive for SMEs scheme were 'effective' in terms of trainees' personal development and their career development. It can be concluded that based on the results of the survey, the training programmes were effective with regards to the trainees.

For the employers, the training programmes were effective for both the financial and non-financial impact of the companies. The nonfinancial impact was more significant than the financial impact. Training programmes were also effective in terms of employee retention for the employers. It can be concluded that based on the results of the survey that the training programmes were effective for the employers.

Against an overall conclusion of effectiveness the Discussion raises a number of areas for consideration for future schemes. Ultimately all of these considerations address impact, in particular as regards the fundamental objectives of improving SME performance through employee training. Three themes are addressed: type and content of training; delivery and the execution of future incentive schemes.

\section{Types and content of training programmes}

Future schemes should emphasize targeted programmes for sectors/industries that are undergoing rapid changes and require new talent skillsets. The future schemes should also have specific training programmes for employers in Peninsular Malaysia and East Malaysia as the needs of employers in the different geographic locations are quite different

Future schemes should focus on programmes which offer certification. They should emphasize certification programmes (e.g. CCNA, and RHCSA) to enable trainees and employers to experience more benefits from sending their employees for training.

Collaboration with international online platforms to widen the option of training programmes is a further recommended development. This would enable employers to enrol their employees for training programmes on international online training platforms (e.g. Coursera) and claim the course fees after completing the course.

More industry experts or personnel within the industry should be encouraged to be certified trainers (under the Train the Trainer programme) and they could then introduce more industry specific training programmes or perform more internal training

The maximum claimable course fees by training providers should be increased to allow them to afford and introduce more advanced training programmes 


\section{Delivery of training programmes}

Training providers should be encouraged to incorporate a variety of interactive training techniques into a programme to keep trainees engaged. Training providers should also increase the practical element and hands-on opportunities for trainees during training. For longer term training programmes, its duration should be divided into phases to enable trainees to practise what they have learnt.

Regular audit of equipment at training providers' premises to ensure compliance to industry standards is recommended.

PSMB should increase the frequency of auditing the training providers to ensure the training equipment used is on par with the needs of a particular training and there is adequate number of training equipment for the trainees to use.

\section{Execution of future incentive schemes}

Conduct more targeted engagement sessions with SME employers to raise awareness about benefits of scheme

PSMB should up its efforts in increasing the awareness level among SMEs on the availability of incentive schemes and the benefits of training for their business and employees.

Act and enforce penalties against errant employers who misuse the scheme to maximize the benefits of future schemes, PSMB should strictly enforce penalties against employers who misuse the scheme. The penalty could include barring them from training for a certain period or imposing a penalty on their training levies. Once an employer has been found to misuse the funds, the employer should be red-flagged in PSMB's database and details of the misuse should be stored in the database for future reference

Improve the quality of the PSMB online portal to be more user-friendly and interactive. PSMB should develop an online portal that addresses all the needs of the trainees, employers, and training providers in a single portal. The portal should also list all registered training providers, their star ratings, their list of trainers, and their relevant experience. The interactive portal should also focus on the benefits which trainees can attain from the training programmes available.

There should be better record-keeping by all parties on details of those that have benefited from the scheme to ensure better accountability. A new database should be created to capture all details of the trainees, employers, and training providers. The database should be complete and accurate and maintained for at least seven years after the training has taken place.

\section{Evaluation and measurement}

Finally we note the need to enhance efforts to evaluate such initiatives. A previous study by Devins \& Johnson, 2002 found that as a general rule, the 'harder' the measure (in terms of financial and market performance), the less influence the training intervention is felt to have had. There were more positive results for 'softer' measures such as confidence and competitiveness. However, that aspect will motivate employers to continuously send employees for training. Whilst 'hard' measures in training will always be problematic financial impact is a crucial measure for employers and convincing them that training would be able to impact them positively. There are 
steps which could usefully be considered. Efforts to assess effectiveness should be made more frequently with both the trainees and employers to ensure that they will be able to recall the details of the training programme they attended. A brief survey could be conducted 6 months after training to gauge satisfaction and immediate impact. Subsequently, a survey 2-3 years after a training programme would give trainees and employers sufficient time to observe any further impact.

\section{Conclusions}

The oversubscription of the Training Incentive Scheme for SMEs has shown the importance of training funds as SMEs often have less access to training resources compared to larger organizations. The popularity of the Scheme has shown some indicators of success in terms of the number of trainees achieved, but more importantly it is showing the dire situation of SMEs in sourcing for additional funds or resources of training, and more targeted assistance should be given to the SMEs.

The quantitative survey results indicate that the training programmes which were part of the Training Incentive for SMEs scheme were effective in terms of trainees' personal development and their career development. It can be concluded that based on the results of the survey, the training programmes were effective with regards to the trainees.

For the employers, the training programmes were effective for both the financial and nonfinancial impact of the companies. The non-financial impact was more significant than the financial impact. Training programmes were also effective in terms of employee retention for the employers. It can be concluded that based on the results of the survey the training programmes were effective for the employers.

Therefore, it can be determined that although there is a need for improvement in certain areas, the training programmes which were part of the scheme have overall been partially effective in training and upgrading employees of SMEs. Similar schemes should be introduced in the future but future implementations of the scheme should focus on fixing the areas that were not effective such as financial impact for the employers. The lack of effectiveness in terms of financial impact could be due to the types of training programmes that were offered as part of the scheme. Whilst positive results for 'softer' measures such as confidence and competitiveness did emerge from the research it remains difficult for trainees and employers to attribute a direct link to financial indicators for training programmes on soft skills or those that were of short duration. Financial impact is a crucial measure for employers and convincing them that training would be able to impact them positively in that aspect will motivate employers to continuously send employees for training.

\section{Notes}

1 PSMB is better known as The Human Resource Development Fund, Malaysia.

2 The Human Resource Development Levy is the mandatory levy payment imposed by the Government on specified groups of employers for the purpose of employee training and skills upgrading. 


\section{References}

Batra, G., \& Tan, H. (2003). SME Technical Efficiency and Its Correlates: Cross-National Evidence and Policy Implications. World Bank Institute.

Devins, D., \& Johnson, S. (2002). Engaging SME Managers and Employees in Training:Lessons from an Evaluation of the ESF Objective 4 Programme in Great Britain. Education \& Training, 44(8/9), 370-377.

Giangreco, A., Carugati, A., \& Sebastiano, A. (2010). Are We Doing the Right Thing? Food for Thought on Training Evaluation and its context. Personnel Review 39(2), 162-177.

Hashim, F. (2012). Challenges For the Internationalisation of SMEs and the Role of Government: The Case of Malaysia. Journal of International Business and Economy 13(1), 97-122.

Lopez-Acevedo, G., \& Tinajero, M. (2010). Mexico: Impact Evaluation of SME Programs Using Panel Firm Data. The World Bank.

Management Development Programme. (September, 2016). Retrieved from http://www.managementworks. ie/programmes

Prime Minister's Department, Malaysia (2010). Tenth Malaysia Plan 2011-2015. Putrajaya: The Economic Planning Unit, Prime Minister's Department. Retrieved from https://www.pmo.gov.my/ dokumenattached/RMK/RMK10_Eds.pdf

Prime Minister's Department, Malaysia (2015). Eleventh Malaysia Plan 2016-2020. Putrajaya: Economic Planning Unit, Prime Minster's Department.

Saleh, A. S., \& Ndubisi, N. O. (August, 2006). An Evaluation of SME Development in Malaysia. International Review of Business Research Papers, 1-14.

SME Corporation Malaysia (2015). SME Annual Report 2014/15. SME Corporation Malaysia. Retrieved from http://www.smecorp.gov.my/index.php/en/resources/2015-12-21-11-07-06/sme-annual-report/ book/7/Array

Ting, O. K. (2004). SMEs in Malaysia: Pivot Points for Change. Retrieved from http://www.mca.org.my

\section{Author}

The author of this article is the Corporate Strategy and Insights Department of Pembangunan Sumber Manusia Berhad (PSMB), Malaysia. Better known as The Human Resources Development Fund (HRDF) PSMB is at the forefront of upskilling and reskilling Malaysia. PSMB was established by the Human Resources Ministry in 1993. Governed by the Pembangunan Sumber Manusia Bhd Act 2001 (PSMB Act 2001), PSMB was given a mandate by the Malaysian Government to catalyse the development of competent local workforce that will contribute to Malaysia's vision of becoming a high-income economy. Related research projects being undertaken include an evaluation of the effectiveness of HRDF Fund and an evaluation of initiatives to enhance apprenticeship in Malaysia. 